\title{
Biology and host preference of Nephopteryx divisella (Lepidoptera: Pyralidae): Candidate agent for biological control of leafy spurge complex in North America ${ }^{1}$
}

\author{
M. CRISTOFARO ${ }^{2}$ F. SALE,${ }^{3}$ G. CAMPOBASSO,${ }^{4}$ L. KNUTSON,${ }^{4}$ and \\ V. SBORDONI ${ }^{3}$ \\ ${ }^{2}$ ENEA C.R. Casaccia, INN BIOAG-ECO, via Anguillarese 301, 00060 Rome, Italy. ${ }^{3}$ Dipartimento di Biologia, Uni- \\ versità di Roma Tor Vergata, via della Ricerca Scientifica, Rome, Italy. ${ }^{4}$ European Biological Control Laboratory, \\ USDA-ARS, Parc Scientifique Agropolis II, 34397 Montpellier, France.
}

\begin{abstract}
:
Euphorbia esula L. (Euphorbiaceae) is a complex of species that has become major weeds in rangelands and pastures in North America. The biology and host specificity of Nephopterix divisella Duponchel (Lepidoptera: Pyralidae) was studied to evaluate its potential as a new biological control agent. This oligophagous, multivoltine stem borer is common on spurges such as E. characias in western and southwestern Europe. The results of no-choice feeding test with 1 st instars, showed that the host range is restricted to plant species in the genus Euphorbia. Among them, feeding on E. milii Desmoulins and E. trigona Haworth, both ornamental plants, seems to bar chances for $N$. divisella to be selected as a leafy spurge biological control agent.
\end{abstract}

\section{Keywords:}

Biological control, insects, leafy spurge, moth, phytophagous, weeds.

Leafy spurge, Euphorbia esula L. (Euphorbiaceae) (=E. virgata Waldstein and Kitaibel by many authors; Dunn 1979), is a complex of species and biotypes of Caucasian origin (Croizat, 1945), distributed in Europe, Russia, and China (Bakke 1936). In the Old World, leafy spurge is not a weed; many natural enemies control the size of the plant populations (Pecora and Dunn 1990). During the past century, E. esula was unintention-

\footnotetext{
${ }^{1}$ Received for publication 5 March 1997; accepted 29 December 1997.
} 
ally introduced into North America (Britton 1921) where it quickly became an irreversibly dominant weed on rangelands and pastures, displacing useful native forage plants (Hanson and Rudd 1933, Reed and Hughes 1970, Dunn 1979, Harris et al. 1985). Currently, the area of most serious infestation in North America is defined by a circle $\approx 2,000$ $\mathrm{km}(\approx 1,200$ miles) in diameter, centered in northeastern Montana (Lacey et al. 1985). The qualities of E. esula, together with some environmental factors, determined this rapid and massive spread. Euphorbia esula is a perennial, emerges early in the spring, propagates sexually from seeds or asexually from root buds, and contains a large nutrient reserve in its roots. In addition, because it is not indigenous to North America, it has few natural enemies (Lacey et al. 1985). It infests pastures and rangelands, producing economic damage by reducing cattle carrying capacity (Dunn 1979). Cattle refuse to eat leafy spurge because of its irritant that causes dermatitis (Kingsbury 1964). Economic losses of over $\$ 100$ million per year (Anonymous 1992) include direct effects and secondary effects on other sectors of the rural economy (agribusiness firms, local trade, and service sectors) (Leistritz et al. 1992).

A biological control program against leafy spurge was started by the Commonwealth Institute of Biological Control for Agriculture Canada in 1962, and by the Agricultural Research Service, U.S. Department of Agriculture, in 1973 (Cristofaro et al. 1994). Seventeen insect species have been evaluated and introduced as biological control agents in North America (Gassman and Schroeder 1995). Although 11 species have become established, it is likely that effective biological control will be achieved only if the combined attack of natural enemies in various climatic zones and habitat types extends over the entire vegetative season (Pecora and Dunn 1990). This article reports on the biology and host range of Nephopteryx divisella Duponchel (Lepidoptera: Pyralidae), a stem-boring moth associated in southern Europe with Euphorbia characias L., a species closely related to leafy spurge.

\section{Materials and methods}

\section{Life History}

Stems of E. characias infested with larvae of $N$. divisella were collected at Marcellina (30 km NE of Rome) from May 1993 to September 1994. The studies were conducted at the Department of Biology, University of Rome, Tor Vergata, Italy. To obtain information on the life history, the insects were reared. Euphorbia characias infested with N. divisella were potted in large cylindrical plastic pots $(65 \mathrm{~cm}$ diameter, $30 \mathrm{~cm}$ high) together with noninfested plants and infested stems cut from E. characias plants. The pots were covered with organdy supported by a plastic framework. The pots were kept in the greenhouse where the temperature ranged from 14 to $35^{\circ} \mathrm{C}$ and the relative humidity from 45 to $85 \%$. Studies were conducted under natural photoperiod. To determine the mean number of eggs per female, single, newly emerged pairs were put in cylindrical, transparent plexiglass cages on potted plants and checked daily to detect oviposition (39 replications). Sixteen fecund females were observed. Incubation and larval developmental periods were calculated for 1,170 hatching eggs and 94 neonate larvae, respectively. Measurements of the head capsule widths of 112 larvae in various instars permitted de-

Page 2 of 9 
termination of the number of instars. To obtain data on pupal longevity, 21 newly formed pupae were reared to adult emergence, and the mean pupal duration was measured. To determine adult longevity, 42 newly emerged adults, together with some stems of $E$. characias, were held separately in cubic wooden cages $(30 \mathrm{~cm}$ long, with a glass side and a net side). To verify the influence of diet, 22 adults were fed with a $10 \%$ honey solution in small petri dishes $(5 \mathrm{~cm}$ diameter) versus the control where only water was offered to 20 adults. Nineteen newly emerged pairs were used to determine the preoviposition period.

\section{Host Range}

Two kinds of tests were conducted to determine host range, a no-choice larval survival test and a choice oviposition test. Larval Survival Test. Neonate larvae were exposed to various test plants under laboratory conditions. The test-plant list included species and biotypes in the family Euphorbiaceae, species in families closely related to Euphorbiaceae, and species economically (alimentary or ornamental value) important (Table 1).

Table 1. Plant species or varieties used in no-choice feeding tests with 1 st instars of $N$. divisella.

\begin{tabular}{|c|c|c|}
\hline Order & Subgenus/Family & Species \\
\hline \multirow[t]{12}{*}{ Euphorbiales } & Esula & E. esula L. (USA) ${ }^{\mathrm{a}}$ \\
\hline & & E. characias L. \\
\hline & & E. ceratocarpa Tenore ${ }^{\mathrm{a}}$ \\
\hline & & E. dendroides L. \\
\hline & Myrsinitae & E. myrsinites L. ${ }^{\mathrm{a}}$ \\
\hline & & E. biglandulosa Desfontaines ${ }^{\mathrm{a}}$ \\
\hline & Euphorbium & E. tirucalli $\mathrm{L}^{\mathrm{a}}$ \\
\hline & & E. milii Desmoulins ${ }^{\mathrm{a}}$ \\
\hline & & E. trigona Haworth ${ }^{\mathrm{b}}$ \\
\hline & Poinsettia & E. pulcherrima Willdenow \\
\hline & & Codiaeum variegatum Blume \\
\hline & & Ricinus communis L. \\
\hline \multirow[t]{7}{*}{ Rosales } & Rosaceae & Malus sylvestris Miller \\
\hline & & Prunus armenica L. \\
\hline & & Prunus avium L. \\
\hline & & Prunus domestica L. \\
\hline & & Prunus dulcis (Miller) Web \\
\hline & & Prunus persica (L.) Batsch \\
\hline & & Pyrus communis L. \\
\hline Fagales & Fagaceae & Castanea sativa Miller \\
\hline Juglandales & Julandaceae & Juglans regia L. \\
\hline \multirow[t]{2}{*}{ Fabales } & Fabaceae & $\begin{array}{l}\text { Robinia pseudoacacia L. } \\
\text { Trifolium } \mathrm{sp} .\end{array}$ \\
\hline & Mimosaceae & Acacia dealbata Link \\
\hline Geraniales & Geraniaceae & Pelargonium sp. \\
\hline \multirow[t]{2}{*}{ Urticales } & Moraceae & Ficus carica L. \\
\hline & Ulmaceae & Ulmus carpinifolia Suckow \\
\hline Asterales & Asteraceae & Lactuca sativa L. (USA) \\
\hline Salicales & Salicaceae & Populus tremula L. \\
\hline Poales & Poaceae & Zea mays L. (USA) \\
\hline
\end{tabular}

Page 3 of 9 
Five neonate larvae were transferred with a small brush onto the tip of each potted test plant, The insects were confined on each test-plant by a transparent plastic cylinder (20 $\mathrm{cm}$ diameter, $60 \mathrm{~cm} \mathrm{high),} \mathrm{with} 2$ holes ( $15 \mathrm{~cm}$ diameter) in the walls and the top covered with a screen to permit aeration. From 3 to 5 replications were conducted. The cages were kept in the greenhouse. Oviposition Test. Five test plants of economic importance, on which complete larval development was observed or plants that had been accepted by the larvae, were selected for a choice oviposition test. The test plants were grown together in large pots (the same kind of pots used in the life history study), then a pair of adults was placed in each pot and we observed the mean number of eggs per pair and the preferred oviposition sites.

\section{Data analysis}

The data were analyzed by using the procedures of the Michigan State University Microcomputer Statistical Program (MSTAT 1986). The variability of the differences in larval survival rate and in the time spent to complete larval development was analyzed with analysis of variance (ANOVA) and with the Duncan (1955) multiple range test.

\section{Results}

\section{Life History}

$N$. divisella is intimately related to E. characias, and it prefers plants growing on dry and sunny sides of calcareous hills. According to Spüler (1908), larvae of $N$. divisella live from September to February on Euphorbia spp. in southern Europe. Lhomme (1935) recorded larvae from November to May on E. characias, E. cyparissias, and other Euphorbia species.

The genus Nephopteryx Hübner belongs to the family Pyralidae Latreille, subfamily Phycitinae Zeller. The number of phycitine species recorded is 4,000 (Solis and Mitter 1992). The subfamily is distributed throughout the world except in the northern and southern extremes. Phycitine larvae are mostly leaf-rollers living in a tube of silk mixed with frass, but a few are inquilines in galls, seed feeders (including stored-product pests), or predaceous on Homoptera (Solis and Mitter 1992).

Three species of Nephopteryx are reported in Europe: $N$. similella Zincken, found in Italy on oak (Quercus spp.); $N$. genistella Duponchel, common in the Corse Island on Ulex spp.; and N. coenulentella Zeller, distributed in southern Europe on plants of the genus Lotus (Spüler 1908, Hasenfuss 1960). In the United States, there are 22 species of Nephopteryx (Heinrich 1956, Poole 1989) and their larvae feed on plants in the Fabaceae, Ulmaceae, Ericaceae, Hamamelidaceae, Anacardiaceae, Salicaceae, and Rosaceae (Doerksen and Neunzig, 1976).

\section{Eggs}

Eggs were laid in clusters (10-50 eggs per cluster); they are $0.5 \pm 0.2$ (mean $\pm \mathrm{SD}$ ) $\mathrm{mm}$ in diameter, whitish and sphericalal flattened. Females laid $71.2 \pm 27.8$ eggs in 
greenhouse conditions. Eggs were laid mostly on stems (517 eggs) but also on the upper (288 eggs) and lower surface (71 eggs) of leaves. The incubation period was $10.0 \pm 2.0$ days, with larvae hatching from $95.64 \%$ of the eggs.

\section{Larvae}

$N$. divisella has 4 instars. The means and the standard deviations of the head capsule width, measured on 112 larvae, were $0.277 \pm 0.013$ for the 1 st, $0.427 \pm 0.047$ for the $2 \mathrm{nd}$, $0.842 \pm 0.125$ for the $3 \mathrm{rd}$, and $1.426 \pm 0.055$ for the 4th instars, respectively. Larvae are light brown with a dark head capsule, a dark and thickened 1st thoracic segment, and 2 brownish-red longitudinal stripes. Larvae were gregarious during the young instars. Groups of 30-50 neonate larvae fed on the meristematic tissue at the top of stems of $E$. characias, causing extensive damage. They spun a silken web, including dry leaves and feces, in which they rested until they penetrated into the stem, where they continued feeding. The last instars were solitary feeders or grouped in clusters of 2 or 3 individuals. Larvae reached the pupal stage in $37.6 \pm 12.3$ under greenhouse conditions.

\section{Pupae}

Mature larvae pupated in silken cocoons spun among the stems or in the silken web. The pupa was brownish-red and the mean length was $52.3 \pm 5.1 \mathrm{~mm}$. The pupal stage lasted $12.0 \pm 4.2$.

\section{Adults}

The adult is $22 \mathrm{~mm}$ long. The forewings are $13 \mathrm{~mm}$ long and dark brown, with a white band running along the fore border; the hind wings are light brown. In the female, the abdomen is larger and thicker than in the male. Adult survival was $5.4 \pm 3.2$ in the presence of the honey solution, whereas in the presence of water, adults survived $4.2 \pm$ 1.6. $N$. divisella is multivoltine. Four generations were observed in the greenhouse (adults emerging in late May, late July, September, and late February). Field notes suggested that the February generation occurred only under greenhouse conditions. Larvae that hatched during September overwintered in the stems of E. characias and reduced their feeding activity. Early the following spring, larvae started feeding again until they achieved complete larval development, emerging as adults during May. Two parasitoids, Sinophorus sp. (Hymenoptera: Ichneumonidae) and Habrobracon sp. (Hymenoptera: Braconidae), were reared from the larvae collected at Marcellina.

\section{Host Range}

Larval Survival Test. Larvae of N. divisella completed development on 7 species, all in the genus Euphorbia: E. esula, E. characias, E. ceratocarpa Tenore, E. myrsinites L., E. biglandulosa Desfontaines, E. tirucalli L. and E. milii Desmoulins (Table 1). Larvae also fed on E. trigona Haworth, but they stopped developing before reaching the pupal stage. No feeding was observed in the family Euphorbiaceae outside the genus Euphorbia 
or in other families. ANOVA conducted on the larval host range and the time spent to complete their development showed significant differences among plant species $(F=$ 18.71, $P<0.01 ; F=5.96, P<0.01$, respectively), whereas differences among replications within a plant species were not significantly different $(F=1.69, P=0.11 ; F=2.14$, $P=0.04$, respectively). The results of the larval survival test on plant species accepted by the larvae are reported in Table 2. All of the larvae completed development on E. ceratocarpa, whereas only $27.7 \%$ of the larvae reached the adult stage on E. esula. The remainder of the test plants showed intermediate values. Larvae took a long time to reach the adult stage on E. milii and E. ceratocarpa, whereas larvae completed development quickly on E. esula, E. characias, and E. tirucalli. Oviposition Test. Oviposition occurred on E. characias, E, esula, E. trigona, and E. milii with significant differences among the plant species, particularly between the target species E. esula and the other species (Table 3).

Table 2. Larval survival test for 1 st instars of $N$. divisella (mean \pm SD)

\begin{tabular}{lccc}
\hline \multicolumn{1}{c}{ Test plants $^{a}$} & No. larvae & $\begin{array}{c}\text { \% larvae completing } \\
\text { development }^{b}\end{array}$ & $\begin{array}{c}\text { No. days to reach } \\
\text { pupal stage }^{c}\end{array}$ \\
\hline E. esula (USA) & 42 & $22.7 \pm 25.6 \mathrm{c}$ & $40.4 \pm 8.9 \mathrm{c}$ \\
E. characias & 42 & $61.7 \pm 40.1 \mathrm{~b}$ & $37.4 \pm 5.4 \mathrm{bc}$ \\
E. ceratocarpa & 42 & $100 \mathrm{a}$ & $71.4 \pm 20.2 \mathrm{a}$ \\
E. myrsinites & 42 & $86.3 \pm 18.3 \mathrm{ab}$ & $34.6 \pm 15.8 \mathrm{abc}$ \\
E. biglandulosa & 40 & $67.7 \pm 21.6 \mathrm{~b}$ & $61.8 \pm 17.3 \mathrm{ab}$ \\
E. tirucalli & 38 & $13.3 \pm 23.3 \mathrm{c}$ & $36.0 \pm 4.4 \mathrm{c}$ \\
E. milii & 31 & $25.3 \pm 30.6 \mathrm{c}$ & $81.5 \pm 56.1 \mathrm{abc}$ \\
\hline
\end{tabular}

${ }^{a}$ Test plants on which development did not occur are reported in Table 1 .

${ }^{b}$ Means (\%) followed by different letters are significantly different at $P<0.01$ (Duncan multiple range test; LSD value $=25.53 ; \mathrm{SEM}=6.76)$.

${ }^{c}$ Means (\%) followed by different letters are significantly different at $P<0.01$ (Duncan multiple range test; LSD value $=35.24 ; \mathrm{SEM}=9.21)$.

\section{Discussion}

Nephopteryx divisella is oligophagous. Our tests confirm that the host range of the larvae is restricted to the genus Euphorbia, 3 in the subgenus Esula (E. esula, E. characias, and E. ceratocarpa), 2 in the subgenus Myrsinitae (E. myrsinites and E. biglandulosa), and 2 in the subgenus Euphorbium (E. tirucalli and E. milii) (Table 1). On E. trigona (subgenus Euphorbium), they reached the last instar, but no pupation was recorded. No feeding occurred on any of the other 22 test plant species (4 Euphorbiaceae and 18 species in other families). According to the percentage of larvae that completed development, the plant species are placed in 3 groups based on the Duncan multiple range test (Table 2): (1) E. ceratocarpa had the greatest value (100\%); (2) E. characias, E. myrsinites, and E. biglandulosa had intermediate values (respectively: 61.7, 86.3, and 67.7\%); and (3) E. esula, E. milii, and E. tirucalli had the lowest values (22.7, 25.3, and $13.3 \%$, respectively). 
Some results were unexpected: although E. characias is the natural host plant of $N$. divisella, it did not show the greatest percentage of larvae that completed development; E. esula is the target species and it is phylogenetically closely related to E. characias (both subgenus Esula) but only $22.3 \%$ of the larvae completed development on it; and species belonging to the subgenus Esula (E. characias, E. esula, and E. ceratocarpa) showed very different values for the percentages of larvae that reached the adult stage.

These results probably can be explained by the poor condition of some E. characias and E. esula plants we used in the tests. In particular, the U.S. biotypes of E. esula did not reach their standard level of growth and the stems were too thin to nourish all of the larvae. In contrast, the time spent completing larval development on the various plant species confirmed the high quality and the close relationship between E. esula and $E$. characias. Euphorbia ceratocarpa showed a high value as to the percentage of larvae that completed development (100\%), but it also showed a high value as to the time spent in completing development (71.4). Euphorbia characias and E. esula showed very low values for the time spent to complete development (37.4 and 40.4, respectively), although they showed mid- to low- percentages of larvae that completed development (61.7 and $22.7 \%$, respectively). This apparent discrepancy between the high nutritious value of $E$. characias and E. esula and their low values in regard to ability of larvae to complete development probably can be explained by the poor condition of the leafy spurge plants, in terms of quantitative but not qualitative food resources.

Concerning the oviposition test, 2 data sets are particularly interesting: (1) the high number of eggs laid on 2 species of economic importance, (E. milii and E. biglandulosa, both in the subgenus Euphorbium), and (2) the low number of eggs laid on the target species, E. esula (Table 3 ). In contrast to a clear oviposition preference, an extremely low percentage of larvae completed development on E. milii and none on E. biglandulosa; this probably means that these 2 species are not suitable larval hosts. The low number of eggs laid on E. esula also could have been due to the poor conditions of the test plants. In fact, $N$. divisella did not lay any eggs on stems of E. esula, although the stems were the most suitable oviposition site. Eggs were laid only on the upper surface of some leaves of $E$. esula. With the exception of the above-mentioned cases, the host specificity tests showed a clear nonsuitability of the other test plant species to $N$. divisella, and this undoubtedly means that $N$. divisella has a host range restricted to the genus Euphorbia.

Table 3. Oviposition rate of $N$. divisella on Euphorbia spp. under choice conditions.

\begin{tabular}{lcl}
\hline Species & No. of eggs laid on test plants & \multicolumn{1}{c}{ Oviposition sites } \\
\hline E. milii & 239 & Stem \\
E. characias & 182 & Stem and upper surface of leaves \\
E. trigona & 115 & Stem \\
E. esula (USA) & 28 & Upper surface of leaves \\
E. tirucalli & 0 & - \\
\hline
\end{tabular}

In conclusion, host suitability preference on ornamental plants, such as E. milii, E. tirucalli, and E. biglandulosa, does not encourage using $N$. divisella as an agent for biological control of E. esula. However, additional host specificity tests, behavioral studies, ecological observations, and genetic studies may better evaluate the degree of specificity of $N$. divisella, because of genetic variability among different populations. 


\section{Acknowledgments}

We are grateful to R. W. Carlson and P. M. Marsh (Systematic Entomology Laboratory, PSI, USDA, Beltsville) for insect identification; G. Allegrucci (Department of Biologia, University of Roma Tor Vergata) for her scientific support and for reviewing the manuscript; M. C. Battista (University of Roma Tor Vergata) and A. C. Pastorino for their help in collecting data; and G. Terragitti (USDA-ARS EBCL, Rome substation) for his technical support.

\section{References cited}

Anonymous. 1992. Economic impact of leafy spurge. Agricultural Experiment Station, NDSU Extension Service, North Dakota State University. Leafy Spurge News 14:4.

Bakke, A. L. 1936. Leafy spurge, Euphorbia esula L. Iowa Res. Stn. Res. Bull. 189:209-245.

Britton, N. L. 1921. The leafy spurge becoming a pest. J. N.Y. Bot. Gard. 22:73-75.

Cristofaro, M., A. Gassman, and P. Pecora. 1994. Biology and host preference of Oxicesta geographica (Lepidoptera: Noctuidae) candidate agent for biological control of Euphorbia esula complex (Euphorbiaceae) in North America. Environ. Entomol. 23:1006-1012.

Croizat, L. 1945. Euphorbia esula in North America. Am. Midl. Nat. 33:131-143.

Doerksen, G. P. and H. H. Neunzig. 1976. Biology of some immature Nephopteryx in the eastern United States (Lepidoptera: Pyralidae: Phycitinae). Ann. Entomol. Soc. Am. 68:423-431.

Duncan, D. B. 1955. Multiple range and multiple F tests. Biometrics 1:1-42.

Dunn, P. H. 1979. The distribution of leafy spurge (Euphorbia esula) and other weedy Euphorbia spp. in the United States. Weed. Sci. 27:509-515.

Gassman, A. and D. Schroeder. 1995. The search for effective biological control agents in Europe: history and lessons from Leafy Spurge (Euphorbia esula L.) and Cypress Spurge (Euphorbia cyparissias L.). Biol. Control 5:466-477.

Hanson, H. C. and Velva E. Budd. 1933. Leafy spurge. Life history and habits. N.D. Agric. Exp. Stn. Fargo. Bull. 266.

Harris, P., P. H. Dunn, D. Schroeder, and R. Vonmoos. 1985. Biological control of leafy spurge in North America. Monogr. Ser. Weed Sci. Soc. Am. 3:79 -92.

Hasenfuss, I. 1960. Die larvalsystematik der zünsler (Pyralidae). Akademie, Berlin.

Heinrich, C. 1956. American moths of the subfamily Phycitinae. U.S. National Museum Bulletin 207. Smithsonian Institution, Washington, DC.

Kingsbury, J. M. 1964. Poisonous plants of the United States and Canada. Prentiss-Hall., Englewood Cliffs. NJ.

Lacey, C. A., P. K. Fay, R. G. Lym, C. G. Messersmith, B. Maxwell, and H. P. Halley. 1985. The distribution, biology and control of leafy spurge. Cooperative Extension Service. Montana State University (in cooperation with North Dakota State University and University of Wyoming), Bozeman.

Leistritz, F. L., F. Thompson, and J. A. Leitch. 1992. Economic impact of leafy spurge (Euphorbia esula) in North Dakota. Weed Sci. 40:275-280.

Page 8 of 9 
Lhomme, L. 1935. Catalogue des Lépidoptéres de France et de Belgique. Microlépidoptères. The author, Le Carriol 2.

[MSTAT] Michigan State Microcomputer Statistical Program. 1986. Microcomputer statistical program: user's guide. Michigan State University, East Lansing.

Pecora, P. and P. H. Dunn. 1990. Insect associations on leafy spurge in Europe: implications for strategies for releases of biological control agents in North America, pp 75-82. In E.S. Delfosse [ed.], First Sperimentale Patologica Veg. (MAF). Proceedings of the VH International Symposium Biological Control of Weeds, 6-11 March 1988, Rome, Italy.

Poole, R. W. 1989. Lepidopterorum Catalogus. 2: Fascimilu. 118. Brill, New York

Reed, C. F. and R. O. Hughes. 1970. Selected weeds of the United States. U.S. Dep. Agric. Handb. 366.

Solis, A. and C. Mitter. 1992. Review and preliminary phylogenetic analysis of the subfamilies of the Pyralidae (sensu strictu) (Lepidoptera: Pyraloidea). Syst. Entomol. 17:79-90.

Spüler, A. 190S. Die Schmetterlinge Europas. I. Band. E. Schweizerbartsche, Stuttgart, Germany. 